УДК 579

\title{
ВЛИЯНИЕ ПЕСТИЦИДОВ НА ФУНКЦИОНИРОВАНИЕ МИКРОБНОГО СООБЩЕСТВА ПОЧВ ЧЕЧЕНСКОЙ РЕСПУБЛИКИ
}

Сельмурзаева Мадина Адамовна Коттоева Макка Тимуровна Берсаева Мадина Рамзановна магистранты

Научные руководители: Дохтукаева Айна Магомедовна кандидат биологических наук

Усаева Яхита Саидовна кандидат биологических наук, доцент ФГБОУ ВО «Чеченский государственный университет»

Аннотация: Для увеличения урожайности в почвах сельскохозяйственного назначения широко применяются различные пестициды, в том числе предназначенные для уничтожения насекомых, вредных для растений, и самой растительности. Микроорганизмы являются тонкими индикаторами устойчивости почвенных экосистем, реагирующими на любые воздействия. Для понимания механизмов оказываемого антропогенного влияния на определенные группы микроорганизмов необходимо изучение их реакций на внесение различных групп пестицидов.

Ключевые слова: пестицид, почва, микроорганизм, бактерии, грибы, воздействие. 


\title{
THE INFLUENCE OF PESTICIDES ON THE FUNCTIONING OF THE MICROBIAL COMMUNITY OF THE SOILS OF THE CHECHEN REPUBLIC
}

\author{
Selmurzaeva Madina Adamovna \\ Kartoeva Makka Timurovna \\ Bersaeva Madina Ramazanovna \\ master's students \\ Scientific supervisors: Dokhtukayeva Aina Magomedovna \\ candidate of biological sciences \\ Usayeva Yakhita Saidovna \\ candidate of biological sciences, associate professor \\ Chechen State University
}

Химические вещества, используемые в большинстве пестицидных смесей, могут убить не только вредителей, но и повредить жизнедеятельности полезных организмов, живущих в почве. Некоторые из этих химикатов могут оставаться в почве в течение многих лет, эффективно препятствуя работе необходимых микроорганизмов.

Когда химикаты используются в течение определенного периода времени на растениях в области, они в конечном итоге выщелачиваются в почву. Попадая в почву, они могут убивать микроорганизмы, живущие в почве, которые разрушают органический материал и способствуют росту растений. Могут пройти годы, прежде чем микроорганизмы снова смогут жить в почве, на которую нанесены токсичные химические вещества. По мере того, как мир становится все более индустриализированным, долгосрочные последствия загрязнения почвы становятся все более серьезной проблемой во всем мире.

Пестициды способны вызывать различные повреждения генетического материала, точечные и хромосомные мутации, которые могут привести к трансформации клеток.

Воздействие пестицидов может вызвать гепаторенальные, неврологические и нейродегенеративные, иммунные, метаболические, эндокринные и психические расстройства. Было выявлено, что среди фермеров, применяющих пестициды, число случаев лейкемии и рака мочевого пузыря было выше, чем в среднем [15]. 
У людей пестициды или их метаболиты действуют преимущественно на уровне центральной нервной системы, изменяя электрофизиологические свойства и ферментативные нейрональные мембраны, вызывающие изменения в кинетике течения ионов натрия и калия через мембрану нервной клетки, что приводит к распространению множественных потенциалов действия для каждого стимула, вызывая такие симптомы, как судороги и остановку дыхания.

В целом, за последние годы накоплено достаточно сведений о пагубном воздействии пестицидов на клетки и ткани человека [1; 4]. При этом, изучение воздействия пестицидов разных групп на почвенные организмы нуждается в уточнении и актуализации.

Гербициды являются экономически эффективным средством борьбы с сорняками с агрономической точки зрения. Однако, долгосрочные проблемы эффективности и устойчивости являются движущими силами пересмотра стратегии борьбы с сорняками, зависящими от гербицидов. Большинство гербицидов показали превосходную эффективность борьбы с сорняками.

В сельском хозяйстве сорняки контролируются различными методами управления, включая использование гербицидов, для увеличения доступности ресурсов участка для получения желательных культур.

В последние годы имеется значительное число исследований о воздействии гербицидов на сорняки, работ по поиску новых препаратов, их механизмах воздействия на микробиоту ризосферы $[7 ; 10 ; 2 ; 3]$.

Одной из новейших стратегий сельского хозяйства является создание культур растений, обладающих устойчивостью к гербицидам. Такие ГМкультуры, устойчивые к гербицидам широкого спектра действия (глифосат и глюфосинат), впервые были выращены в промышленных масштабах в 1990-х годах [17], а ГМ-культуры, обладающие устойчивостью к другим гербицидам, находятся в стадии разработки [14]. Другой, более недавней стратегией является разработка растений, которые устойчивы к высоким концентрациям глифосата, не демонстрируя снижения урожайности [13].

Глифосат - фосфонометилглицин - полярная, водорастворимая органическая кислота, является сильнодействующим хелатором, который легко связывает двухвалентные катионы (например, $\mathrm{Ca}, \mathrm{Mg}, \mathrm{Mn}$ и $\mathrm{Fe}$ ) и образует стабильные комплексы [9].

В дополнение к активному ингредиенту, который может присутствовать в различных концентрациях, гербициды обычно содержат адъюванты или 
поверхностно-активные вещества, которые способствуют проникновению активного ингредиента через восковые поверхности обработанных растений.

Токсичность составов для клеток человека значительно варьируется в зависимости от концентрации [16]. Исследования свидетельствуют, что деградация глифосата происходит быстро (период полураспада до 130 дней), но его основной метаболит аминометилфосфоновая кислота разлагается мед леннее [8]. Глифосат по-разному влияет на состав микробиоты почвы и желудочно-кишечного тракта макроорганизмов, подавляя одни микроорганизмы и благоприятствуя другим. По мнению исследователей, это может быть связано с различной чувствительностью бактериальных ферментов к глифосату. Воздействие глифосата на грибы также варьируется в зависимости от мест исследования, вида, инокулята возбудителя, сроков применения гербицидов, свойств почвы и обработки почвы. Показано, что микоризные грибы чувствительны к глифосату, в то время как другие, включая патогенный Fusarium, грибы могут использовать глифосат как питательное вещество и источник энергии. Также есть свидетельства того, что патогенные бактерии (например, сальмонелла и клостридий) менее чувствительны к глифосату, чем полезные бактерии, например молочнокислые бактерии. По этой причине необходимы исследования влияния глифосата на кишечный микробиом других видов $[11 ; 12]$.

Фунгициды как одна из групп применяемых пестицидов широко используются в развитых сельскохозяйственных системах для борьбы с грибковыми болезнями растений и обеспечения урожайности и качества сельскохозяйственных культур. В последнее время агрохозяйственники сталкиваются с проблемой резистентности патогенных грибков ко многим наиболее эффективным фунгицидам, что ставит под угрозу контроль фитозаболеваний.

Последовательное появление организмов с пониженной чувствительностью к наиболее активным фунгицидам иллюстрируют непрерывный эволюционный процесс в ответ на введение и использование различных химических классов веществ [7].

Системным фунгицидом, широко применяемым в сельском хозяйстве, является «Превикур Энерджи», который предназначен для борьбы и профилактики таких заболеваний культурных растений как фитофтороз, черная ножка капусты, пероноспороз, прикорневая и корневая гниль и другими. Препарат оказывает свое губительное воздействие против грибов, поражающих 
все части растений, включая семена, побеги, листья и плоды. Кроме того, «Превикур Энерджи» выполняет защитную функцию для организма растения, повышает иммунитет растений к грибковым и бактериальным заболеваниям, способствует активации роста побегов и развитию корневой системы [6].

Выделение мицеллиальных организмов грибов методом посева из почвенной суспензии на агаризованные питательные среды дает возможность обнаружить и определить качественный состав микроскопических грибов, содержащихся в образце почве.

Для прямого учета грибов в образцах почвы применяли метод мембранных фильтров и микроскопирования.

Для идентификации и определения таксономического положения выделенных грибов определяли их культуральные и морфологические признаки, изучали и описывали строение репродуктивных органов.

Результаты исследования численности грибов, актинобактерий и эубактерий почвы представлены в табл.1.

Таблица 1

Численность клеток почвенных микроорганизмов в почве

\begin{tabular}{|c|c|c|c|}
\hline $\begin{array}{c}\text { Точки отбора } \\
\text { проб }\end{array}$ & $\begin{array}{c}\text { Количество } \\
\text { грибов, КОЕ/ }\end{array}$ & $\begin{array}{c}\text { Количество } \\
\text { актинобактерий, } \\
\text { КОЕ/г }\end{array}$ & $\begin{array}{c}\text { Количество } \\
\text { бактерий, КОЕ/ г }\end{array}$ \\
\hline № 1 & $0,8 \pm 0,04 \cdot 10^{3}$ & $2,25 \pm 0,06 \cdot 10^{5}$ & $2,9 \pm 0,65 \cdot 10^{6}$ \\
\hline № 2 & $1,8 \pm 0,55 \cdot 10^{3}$ & $1,95 \pm 0,05 \cdot 10^{5}$ & $2,4 \pm 0,72 \cdot 10^{6}$ \\
\hline
\end{tabular}

Численность клеток актинобакетрий и эубактерий в отобранных пробах почвы была сопоставима. Отмечено, что в районах без воздействия пестицидов (точка № 2) актинобактерий и эубактерий было меньше, чем в пробе точки № 1, районе воздействия пестицидов.

Данный факт, вероятно, связан с освобождением бактериального сообщества от конкурентного воздействия грибного компонента ценоза. В этой связи, для актинобактерий и бактерий как организмов, подвергающихся в природных сообществах прессингу со стороны микобионтов, в почвах с воздействием пестицидов складываются более благоприятные для размножения 
условия. Этот факт в свою очередь обусловлен тем, что пестициды имеют специфичность воздействия на грибное сообщество и растительные сорняки.

Для наглядности результаты представлены в виде рисунка 1, на котором отчетливо видно большее количество бактерий в почвах с воздействием пестицидов.

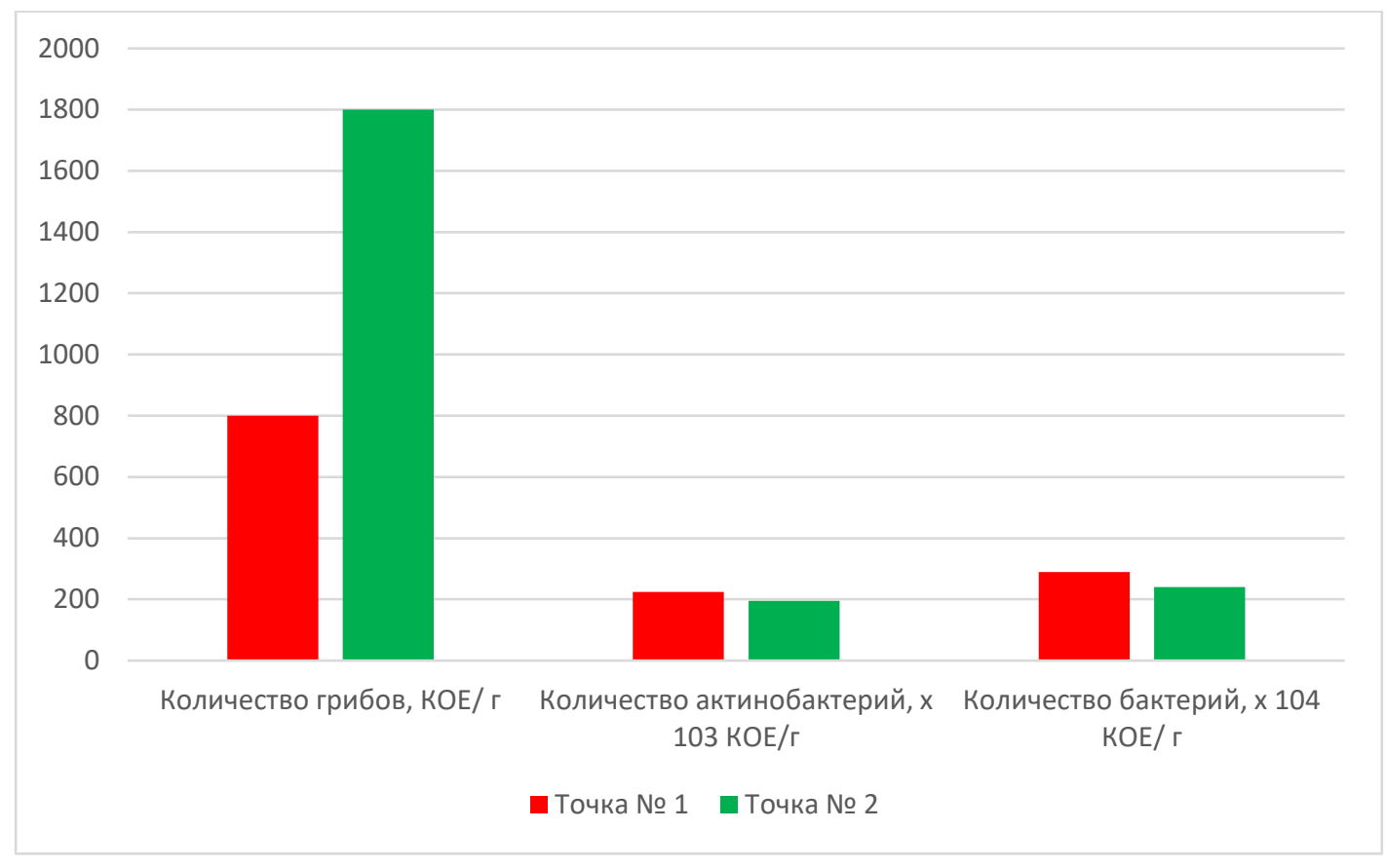

\section{Рис. 1. Количественный состав почвенных микроорганизмов с воздействием пестицидов и в контроле (точка № 2)}

Таким образом, выявлено, что количество грибов в почвах в 1000 раз меньше количества эубактерий и в 100 раз меньше актинобактерий. При этом, показано, что воздействие пестицидов имеет специфическую направленность в отношении эукариотических клеток грибных организмов, оказывая даже стимулирующее воздействие на прокариот, к которым относится основная часть бактериального ценоза почв. При этом гербицидные препараты бактериальное сообщество может воспринимать в качестве питательных веществ. Известно, что бациллы, псевдомонады, актинобактерии способны к синтезу разнообразных ферментов и расщеплению даже сложноразлагаемых химических соединений. Увеличение количества бактерий в ценозе свидетельствует о создании в районах воздействия пестицидов благоприятных условий для развития, то есть воздействие пестицидов не оказывает существенного влияния на бактериальное сообщество. 


\section{Список литературы}

[1] Аксенов, В.А. Влияние пестицидов на организм. Проблемы обращения с пестицидами / В.А. Аксенов, И.В. Шиховцева// В сборнике: Актуальные проблемы экологии и охраны труда сборник статей VIII Международной научно-практической конференции: в 2 частях. - 2016. - С. 42 46.

[2] Глазко, В.И. Изменение ферментных спектров почвенных микроорганизмов Micrococcus luteus CCM248 и Stenotrophomonas maltophilia УКМ В-257 под влиянием некоторых пестицидов / В.И. Глазко, Т.Т. Глазко, Г.А. Иутинская, Н.И. Ямборко // Докл. РАСХН. - 2006. - № 3. - С. 27-31 .

[3] Гончаров, Н.Р. Развитие инновационных процессов в защите растений /Н.Р. Гончаров // Защита и карантин растений. - 2010. - № 4. - С. 4-8.

[4] Завьялова, Я.С. Влияние пестицидов на организм человека/

Я.С. Завьялова, В.Д. Богданова //Medicus. - 2017. - № 1 (13). - C. 16-18.

[5] Клочкова, О.П. Комплексная научная оценка средств защиты растений Бетанал эксперт оф, Атрибут, Превикур Энерджи, Консенто /О.П. Клочкова //Здоровье и окружающая среда. - 2013. - № 22. - С. 172-175.

[6] Поддымкина, Л.М. Динамика разложения пропамокарба гидрохлорида при применении препарата Превикура Энерджи на растениях томата/ Л.М. Поддымкина, Г.Е. Ларина, А.В. Калинин [и др.]//Земледелие. 2019. - № 4. - C. 44-48.

[7] Спиридонов, Ю.Я. Современные проблемы изучения гербицидов (2006-2008 гг.) г. / Ю.Я. Спиридонов, С.Г. Жемчужин// Агрохимия. - 2010. - № 7. - C. 73-91.

[8] Borggaard, O.K. Fate of glyphosate in soil and the possibility of leaching to ground and surface waters: a review/O.K. Borggaard, A.L. Gimsing// Pest Manag Sci. - 2008. - 64. - P.:441-456.

[9] Cakmak, I. Glyphosate reduced seed and leaf concentrations of calcium, manganese, magnesium, and iron in non-glyphosate resistant soybean / I. Cakmak, A. Yazici, Y. Tutus [et al]// Eur J Agron. - 2009. - 31(3). - P.114-119.

[10] Chen, В. Влияние метолахлора на биологическую активность ризосферы сельдерея и неризосферной почвы/ B. Chen, D. Xu, G. Liu, W. Liu // Chin. J. Appl. Ecol. - 2006. -V. 17. -№ 5. - P. 925-928.

[11] Clair, E. Effects of Roundup and glyphosate on three food microorganisms: Geotrichum candidum, Lactococcus lactis subsp. cremoris and 
Lactobacillus delbrueckii subsp. Bulgaricus /E. Clair, L. Linn, C. Travert [et al]// Curr Microbiol. - 2012. - 64(5). - P.486-491.

[12] Druille, M. Arbuscular mycorrhizal fungi are directly and indirectly affected by glyphosate application/ M. Druille, M. Omacini, R.A. Golluscio [et al]// Appl Soil Ecol. - 2013. - 72. - P.143-149.

[13] Dun, B. Development of highly glyphosate-tolerant tobacco by coexpression of glyphosate acetyltransferase gat and EPSPS G2-aroA genes /B. Dun, X. Wang, W. Lu [et al]// Crop J. - 2014. - 2(2-3). - P.164-169.

[14] Green, J.M. Current state of herbicides in herbicide-resistant crops/ J.M. Green //Pest Manag Sci. - 2014. - 70(9). - P.1351-1357.

[15] Larrea, M. Genotoxic damage caused by exposure to pesticides in farmers Luribay Township /M. Larrea, N. Tirado, M.E. Azcarrunz// Biofarbo. - 2010. $-18(2)$. - P.31-43.

[16] Mesnage R, Bernay B, Séralini GE (2013) Ethoxylated adjuvants of glyphosate-based herbicides are active principles of human cell toxicity. Toxicology 131(2-3):122-128.

[17] Nandula, V.K. Glyphosate resistance in crops and weeds: history, development, and management / V.K. Nandula //Wiley, Hoboken. - 2010. - p. 6791.

(C) М.А. Сельмурзаева, М.Т. Коттоева, М.Р. Берсаева, 2021 